\title{
Nitrogen and phosphorus as production limiting factors in the estuarine waters of the eastern Gulf of Finland
}

\author{
Heikki Pitkänen*, Timo Tamminen \\ Finnish Environment Agency, PO Box 140, FIN-00251 Helsinki, Finland
}

\begin{abstract}
The fate and effects of high nutrient loading from the River Neva - St. Petersburg (NW Russia) region was studied in the Neva Estuary and adjacent waters of the eastern Gulf of Finland (Baltic Sea) under late summer conditions. Special emphasis was given to the role of $\mathrm{N}$ and $\mathrm{P}$ as production limiting factors. The data originated from 5 cruises performed in 1990-1992 and include CTD measurements and spatial distributions of different nutrient fractions as well as nutrient depletion measurements onboard. The results revealed quick losses of both total and inorganic nutrients from the euphotic layer of the inner estuary under varying physical conditions. On the basis of nutrient depletion experiments, the very striking non-conservative behaviour of inorganic nutrients was explained by effective biological fixation of nutrients into planktonic biomass, followed by sedimentation. For total nutrients, physico-chemical loss processes might also be important in the salinity gradient prevailing in the inner estuary. The theoretical limiting nutrient for planktonic production varied according to the physical state of the water mass, especially to vertical mixing conditions. In general the inner estuary was P limited, while the open eastern Gulf was mainly $N$ limited. In the outer estuary low mixed layer depth (MLD) favoured N limitation, while thick MLD (i.e. windy weather) favoured P limitation. This indicates that reduction of both $N$ and $P$ load into the eastern Gulf would improve water quality in this area. However, effective $N$ removal would probably induce the most extensive improvement in the trophic status of the entire Gulf of Finland.
\end{abstract}

KEY WORDS: Nitrogen P Phosphorus · Nutrient limitation $\cdot$ Nutrient depletion rate $\cdot$ Estuaries $\cdot$ Baltic Sea

\section{INTRODUCTION}

In recent eutrophication studies of the Baltic Sea, much attention has been paid to pelagic nutrient dynamics, including the concept of limiting factors (e.g. Stigebrand \& Wulff 1989, Granéli et al. 1990, Tamminen 1990, Kivi et al. 1993, Kuparinen \& Heinänen 1993). Because the whole Baltic Sea is extensively affected by its catchment area $\left(1.7 \times 10^{6} \mathrm{~km}^{2}, 4.5\right.$ times larger than the Baltic Sea itself), influxes of nutrients via the major rivers (Neva, Daugava, Vistula etc.) that discharge into this enclosed brackish water sea area evidently greatly affect nutrient conditions. However, studies on nutrient and eutrophication dynamics in the

•E-mail: heikki.pitkanen@vyh.fi most loaded estuarine areas (Gulf of Riga, eastern Gulf of Finland) were not done until in the 1990s (Pitkänen et al. 1993, Yurkovskis et al. 1993).

The Gulf of Finland, part of the northern Baltic Sea, is very strongly affected by river waters, especially from the River Neva. Due to heavy loading and estuarine hydrodynamics, extensive adverse signs of eutrophication are regularly found during the spring bloom period in the entire Gulf (Grönlund \& Leppänen 1990) and during the whole productive season in the easternmost Gulf (Pitkänen et al. 1993, Kauppila et al. 1995). In the middle and western Gulf summertime blooms are occasional, and they are connected with vertical mixing events near the coasts (upwelling) or with quasistationary physical fronts in open waters (Kononen \& Nômmann 1992). 


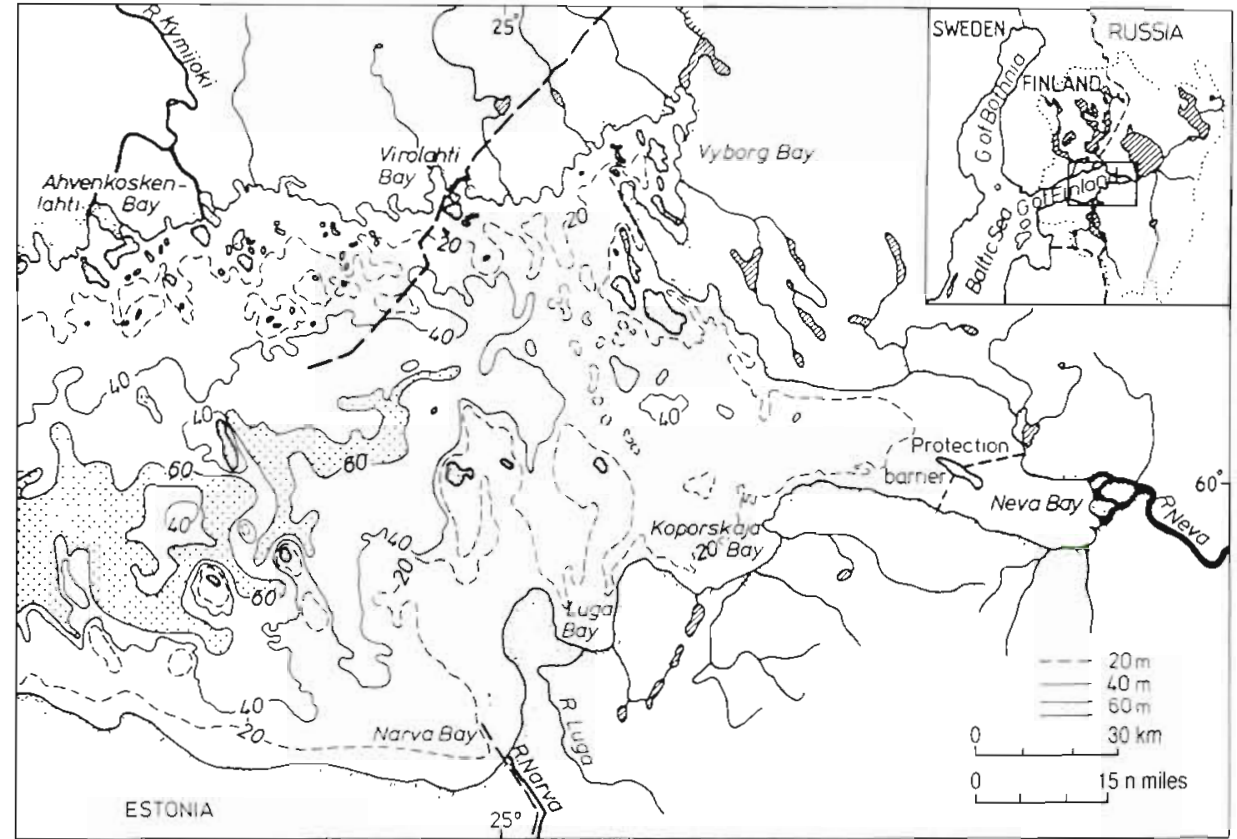

Fig. 1. The study area, eastern Gulf of Finland, Baltic Sea
The western Gulf has been regarded mainly as $N$ limited during most of the productive season (Tamminen 1990, Kivi et al. 1993). On the other hand, the easternmost Gulf, receiving a great freshwater flow from. the River Neva and waste waters from the St. Petersburg region (NW Russia), is characterized by inorganic $\mathrm{N}: \mathrm{P}$ ratios (ca $20 \mathrm{w}: \mathrm{w}$ ) 3 times the theoretical optimum for phytoplankton ( $7 \mathrm{w}: w_{i}$ Redfield et al. 1963). These waters have an average flow direction to the west, mainly along the northern (Finnish) coast of the Gulf The deep flow, which has an average eastward direction and mixes with the surface flow especially in the Neva Estuary, shows lower inorganic N:P ratios (5 to 10; Pitkänen et al. 1993). The inorganic $N$ :P ratio has steadily increased in deep layers in the Gulf of Finland, because of a continuous increase of inorganic $\mathrm{N}$ during the 1970s and the 1980s (Kahma and Voipio 1990).

In the present study, the fate and effects of the huge nutrient loading from the River Neva and the St. Petersburg region (ca 6 million inhabitants) was examined under varying late summer (August) conditions. Especially the nutrient limitation $(N, P)$ of the area was considered in relation to the nutrient loading and the dynamic hydrographical nature of the estuary. In estuarine systems, seasonal or spatial shifts between $\mathrm{N}$ and $P$ limitation have been reported elsewhere, and internal nutrient cycling processes have been suggested to play an important role in limitation dynamics (Caraco 1988). The study was based on water samples and experimental data obtained during 3 Finnish-Russian joint cruises ( 5 different data sets along the salinity gradient from the open Gulf towards the mouth of the
River Neval in the eastern Gulf between 1990 and 1992

\section{STUDY AREA}

The eastern Gulf of Finland (area $13000 \mathrm{~km}^{2}$, Fig. 1) can be divided into 4 main subareas according to the geomorphological and hydrodynamical features (Fig. 2; Pitkänen et al. 1993). The 2 easternmost areas form the Neva Estuary, separated from the open Gulf by a belt of islands, reefs and shallows (referred as the transition zone or the gradient area). The water area immediately off the mouth of the River Neva (Neva Bay) is separated from the main part of the estuary by a flood protection barrier. The western border of the eastern Gulf can be defined along the belt of shallows from the Finnish coast to the Estonian coast via the islands of Suursaari and Lavansaari. The Finnish northeastern archipelago forms its own subarea, with special geomorphological and hydrodynamical features.

The average summertime inflow from the River Neva is $2460 \mathrm{~m}^{3} \mathrm{~s}^{-1}$ (Bergström \& Carlsson 1994) and the theoretical residence time of the eastern Gulf of Finland ca 1. year (Pitkänen 1991). Surface salinities of the study area increase from 0 psu in Neva Bay to 4 to 5 psu in the open eastern Gulf, whereas in near-bottom waters salinities are 4 to 8 psu. (Pitkänen et al. 1993) The halocline is weak or totally absent. The gradually increasing salinities below the mixed surface layer (usually 10 to $25 \mathrm{~m}$ thick) indicate almost continuous 
Fig. 2. Sampling stations and subarea division

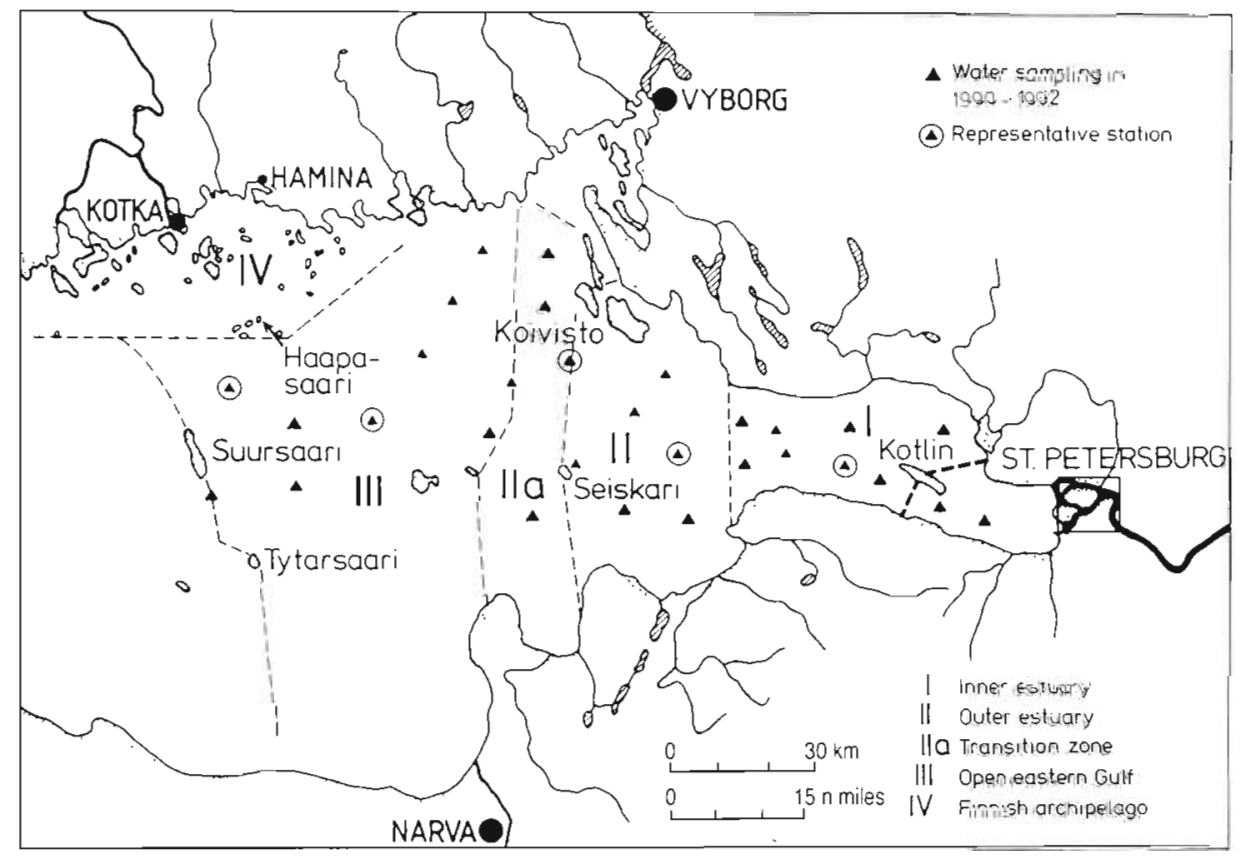

vertical mixing despite the density differences. However, the thermocline partly separates the nutrient-rich deeper waters from the homogenous euphotic layer elsewhere, except in the shallow innermost estuary.

In the whole estuary both primary productivity and biomasses of auto- and heterotrophic organisms are on a highly increased level compared to the open Gulf (Pitkänen et al. 1993, Kauppila et al. 1995), mainly due to the eutrophying effects of the large land-derived nutrient inflow into Neva Bay and to the eastern Gulf of Finland (7200 t $\mathrm{P} \mathrm{yr}^{-1}$ and 130000 t $\mathrm{Nyr}^{-1}$; Pitkänen 1991). Maximum primary and secondary productivities and biomasses are usually found in the transition zone between the inner and outer estuaries, where both physical and chemical conditions favour biological production. Via recycled and secondary effects the huge nutrient loading from the River Neva and the St. Petersburg region increases the productivity of the whole Gulf.

\section{MATERIAL AND METHODS}

The material originates from 5 east-west data sets obtained during cruises in August 1990 to 1992 (18 to 23 August 1990, 19 to 21 August 1991, 24 to 28 August 1991, 10 to 12 August 1992, 14 to 18 August 1992). Sampling stations varied somewhat from year to year but the basic station network along the salinity gradient from Neva Bay towards the open Gulf remained the same (Fig, 2). Most of the data presented in this study compiles all surface layer measurements (average from 0 to $5 \mathrm{~m}$ ), disregarding some near-coastal sta- tions. Additionally, 4 representative stations were chosen to illustrate vertical distribution of selected variables in the different subareas (inner estuary, outer estuary, transition zone at the entrance to the estuary, open Gulf).

Inorganic mutrients were analyzed immediately after sampling, while samples for total nutrients (nonfiltered samples, representing thus the sum of particulate and dissolved fractions) were deep-frozen for later analysis. The sum of dissolved inorganic nitrogen is denoted as DIN $\left(\mathrm{NO}_{3}+\mathrm{NH}_{4}\right)$ and correspondingly for phosphorus, DIP $\left(\mathrm{PO}_{4}\right)$. Chemical analyses followed Grasshoff (1976). With the exception of nutrient depletion experiments, the methods for sampling and measurement of the presented data were similar to those described in detail in Pitkänen et al. (1993), where a more detailed presentation of the 1990 cruise results can also be found. In addition temperature, salinity, $\mathrm{pH}$ and oxygen were measured by CTD casts during the 19911992 cruises instead of laboratory measurements from discrete water samples in 1990

Nutrient depletion experiments were carried out as deck incubations during the cruise. Surface layer water ( 0 to $2 \mathrm{~m}$ ) was sampled and divided into $2 \mathrm{l}$ bottles, where nutrient additions $\left(\mathrm{NO}_{3}-\mathrm{N}, \mathrm{NH}_{4}-\mathrm{N}, \mathrm{PO}_{4}-\mathrm{P}\right)$ were performed (10 $\mathrm{mg} \mathrm{P} \mathrm{m}^{-3}, 40 \mathrm{mg} \mathrm{N} \mathrm{m}^{-3}$ ). Depletion rates were calculated as the difference per unit time between start- and end-point concentrations (measured in duplicate). Incubations started at daytime and were terminated at the end of the light cycle (incubation time 3 to $12 \mathrm{~h}$, depending on expected depletion rates). 
In this paper, the classical approach using sea salt as a conservative variable in assessing the conservative/nonconservative spatial dynamics of nutrients was adopted. Due to a clear density stratification in the study area, an important physical variable strongly affecting the whole biogeochemical system is the mixed surface layer depth (MLD). MLD was defined as the thickness of the homogeneous surface layer (lower limit estimated on the basis of the CTD casts: starting depth of the pycnocline, or in the absence of a sharp pycnocline, the depth where the difference from surface density was less than $0.5 \sigma_{\mathrm{T}}$ units).

\section{RESULTS}

\section{Salinity, density and the mixed layer depth}

From Neva Bay fresh water $(<0.1$ psu) flowed to the west, starting to mix with the brackish water immediately outside the flood protection barrier (15 $\mathrm{n}$ miles from the river mouth, Fig. 3a). Surface salinities rapidly reached 1.5 psu within the inner estuary. An area of very intense vertical mixing was found in the transition zone between the inner and outer estuaries ( $40 \mathrm{n}$ miles from the river mouth). In the deeper outer estuary, more stagnant conditions prevailed with surface salin-
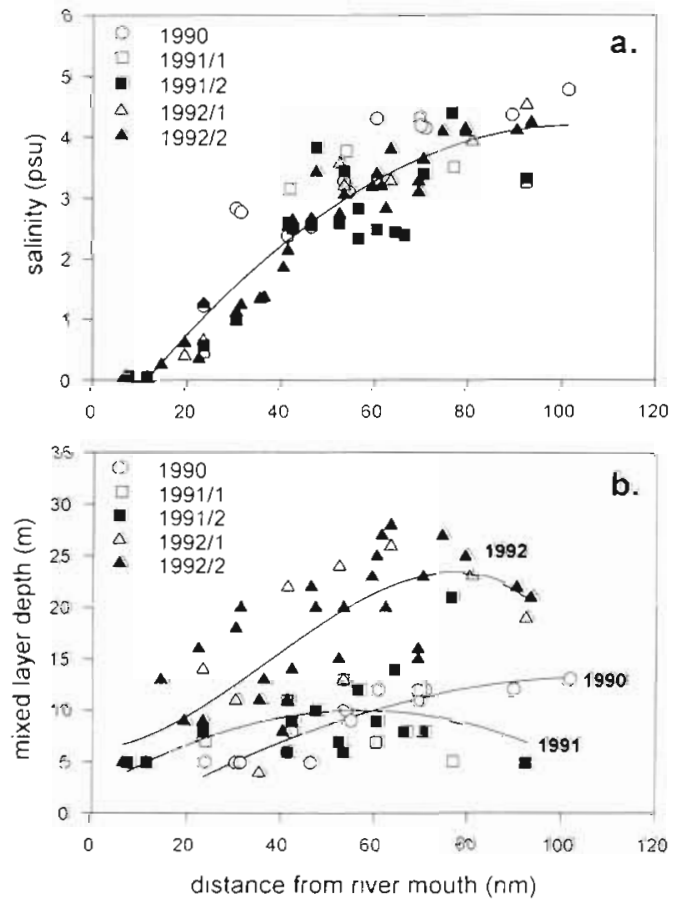

Fig. 3. (a) Surface salinity and (b) mixed surface layer depth (MLD) vs distance (in nautical miles, $\mathrm{nm}$ ) from the mouth of the River Neva dunng cruises in August 1990-1992. Curves are fitted with polynomial regressions for all data (a) or separately for each year (b) ities from 2.5 to 4 psu, the level being horizontally quite steady, but varying temporally according to actual physical stratification of the water mass, as determined by weather conditions. In the transition zone between the outer estuary and the open Gulf (60 to $70 \mathrm{n}$ miles from the river mouth), surface salinities increased to levels typical of the open eastern Gulf (4 to 5 psu).

MLD typically increased from the inner estuary (usually 5 to $10 \mathrm{~m}$ ) towards the open Gulf (up to $27 \mathrm{~m}$, Fig. 3b). There was much variation between the cruises of the different years. However, during the 2 successive cruises in both 1991 and 1992, physical stratification was quite similar.

In August 1990 northwesterly winds between 3 and $7 \mathrm{~m} \mathrm{~s}^{-1}$ predominated. MLD was from 5 to $10 \mathrm{~m}$ in the estuary and from 10 to $15 \mathrm{~m}$ in the open Gulf (Figs. 3b $\& 4$ ). During the first cruise in 1991 westerly winds between 2 and $9 \mathrm{~m} \mathrm{~s}^{-1}$ prevailed. One week later the wind had turned to east and blew from 3 to $7 \mathrm{~m} \mathrm{~s}^{-1}$. Surface salinities were 0.5 to 1 psu lower than normal in the whole study area. During both cruises, the homogeneous low-salinity surface layer (MLD from 5 to $10 \mathrm{~m}$.) mixed gradually with deeper waters (Figs. $3 \mathrm{~b}$ $\& 4$ ). Because the thickness of the euphotic layer increased from $5 \mathrm{~m}$ in the inner estuary up to $10 \mathrm{~m}$ in the open Gulf, the MLD corresponded closely to the euphotic layer This kind of stratification is typical for March-May in the eastern Gulf of Finland, but very rare for late summer.

During the 1992 cruise the hydrographical situation was very different than that of the previous year, mostly because of heavier winds (up to $11 \mathrm{~m} \mathrm{~s}^{-1}$ ) from the south and west. The MLD increased from 10 to $20 \mathrm{~m}$ in the inner estuary to 20 to $30 \mathrm{~m}$ in the open Gulf (Figs. 3b \& 4). Thus the continuously circulating water volume was 1.5 to 3 times to that in August 1991, and was mostly aphotic.

\section{Horizontal variation of nutrients}

Surface layer concentrations of both total $\mathrm{N}$ and total $P$ decreased very strongly from the innermost Neva Estuary $\left(700\right.$ to $1000 \mathrm{mg} \mathrm{N} \mathrm{m}^{-3}$ and 50 to $85 \mathrm{mg} \mathrm{P} \mathrm{m}^{-3}$. Fig $5 \mathrm{a}$, b) towards the open eastern Gulf (250 to 400 $\mathrm{mg} \mathrm{N} \mathrm{m}^{-3}$ and ca $20 \mathrm{mg} \mathrm{P} \mathrm{m} \mathrm{m}^{-3}$ ). For both nutrients a distinct non-conservative behaviour was evident, the most effective losses taking place in the inner estuary. Despite of varying physical conditions, total nutrients exhibited surprisingly similar responses to the longitudinal salinity variations (i.e. the ratio between freshwater and brackish water) during the different cruises. However, in 1992 the outer estuarine concentrations were somewhat higher than in 1990-1991 
Fig. 4. Vertical variation of density $\left(\sigma_{T}\right)$ in August 1990-1992 at 4 stations representing different subareas of the eastern Gulf of Finland
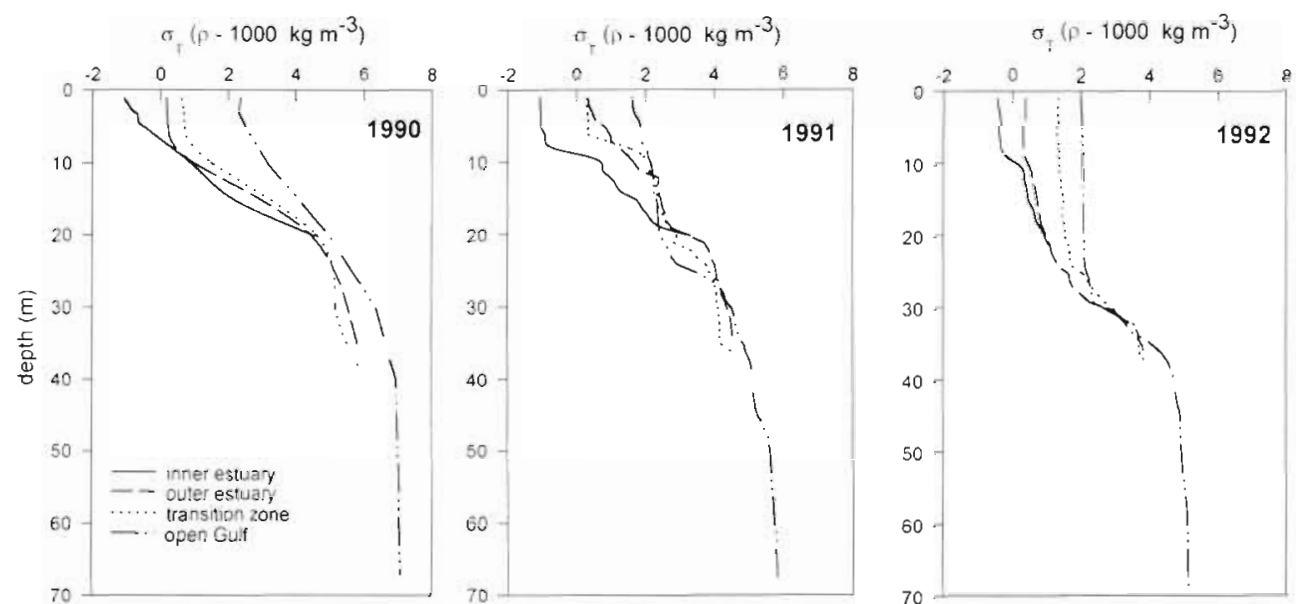
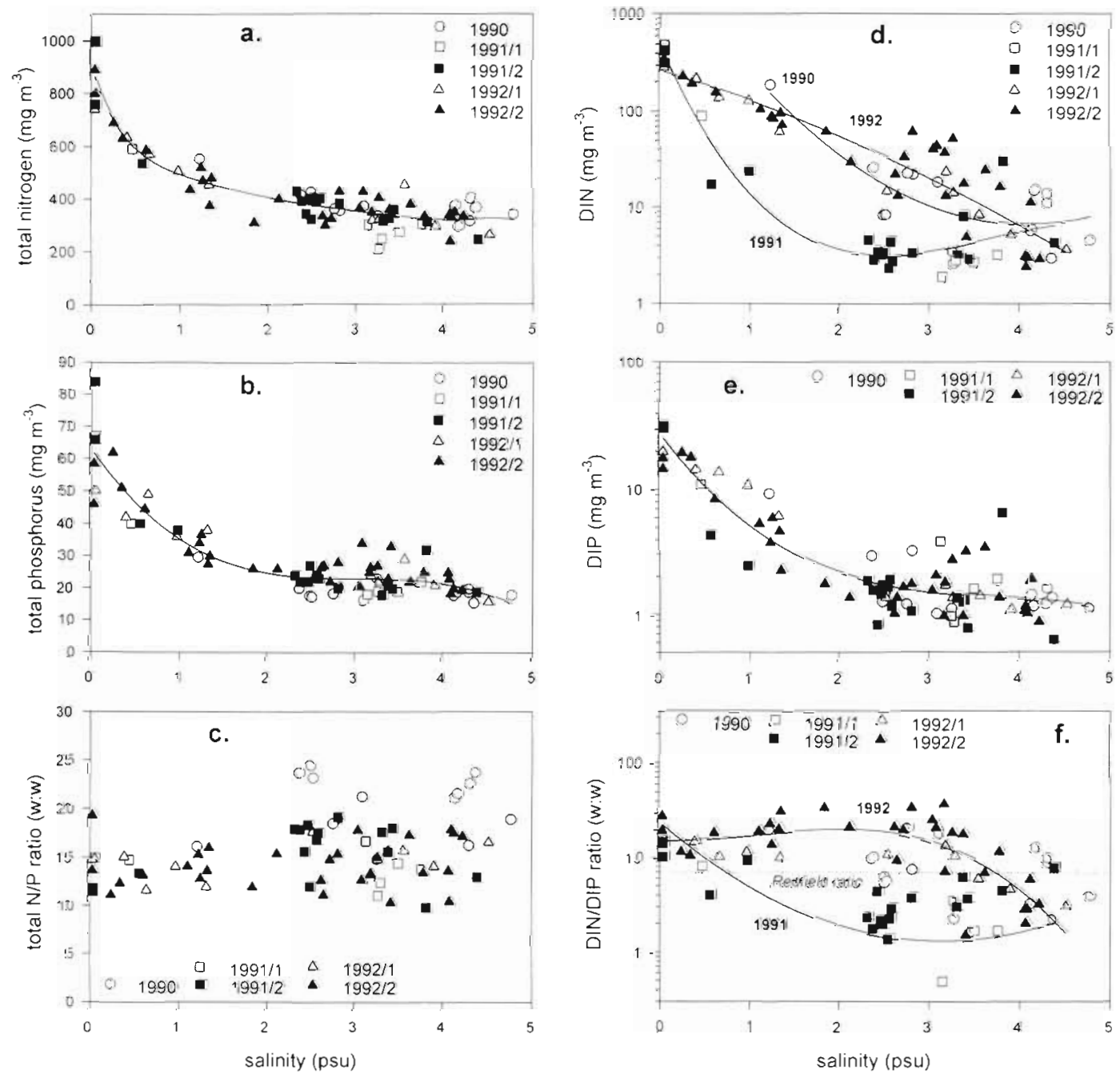

Fig. 5. Surface layer $(0$ to $5 \mathrm{~m}$ ) concentrations vs salınity of (a) total $N$, (b) total $P$, (c) total N:P ratio, (d) inorganic N (DIN), (e) inorganic P (DIP), and (f) inorganic N:P ratio during cruises in August 1990-1992. Curves in figures have been fitted by polynominal regressions for all data except where otherwise indicated 


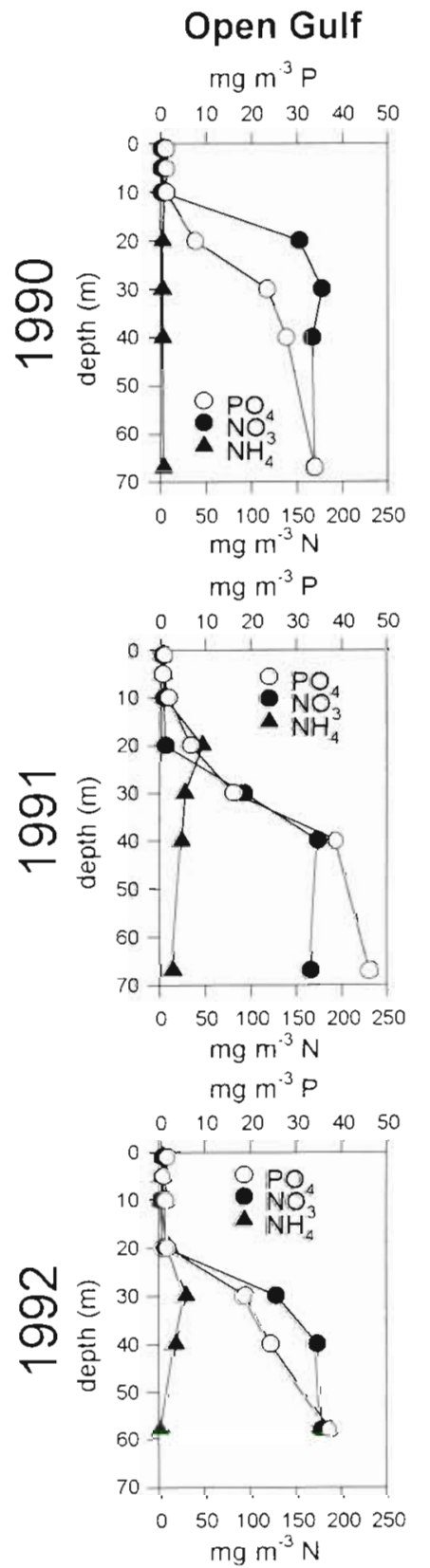

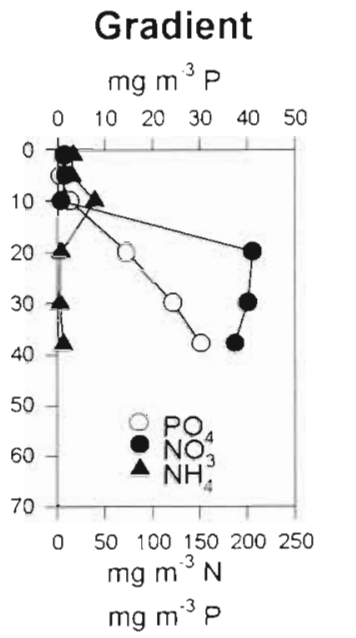
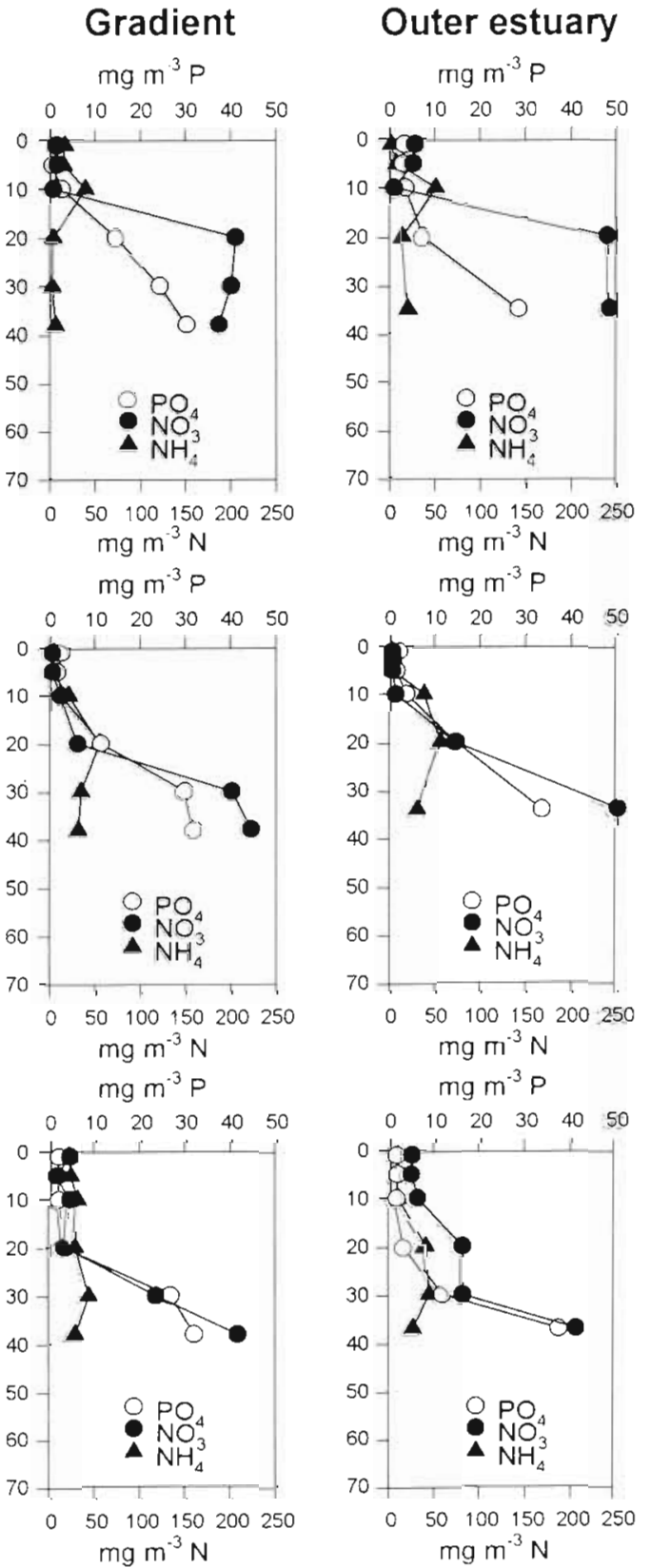

Inner estuary

$\mathrm{mg} \mathrm{m}^{-3} \mathrm{P}$

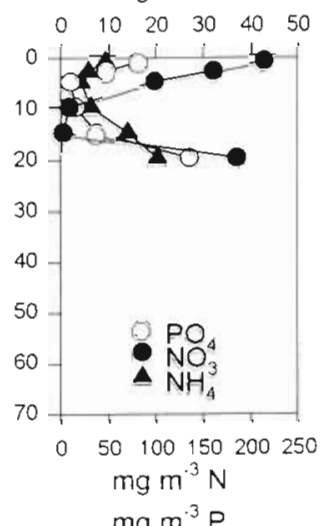

$m g m^{3} \mathrm{P}$

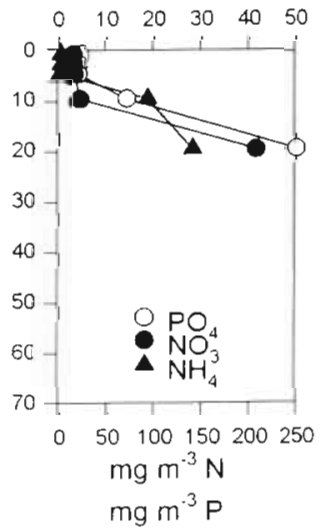

$0 \quad 10 \quad 20 \quad 30 \quad 40 \quad 50$

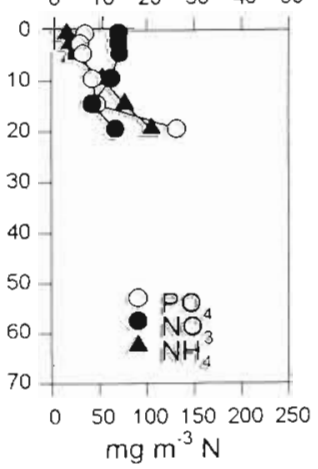

Fig. 6. Vertical distribution of $\mathrm{NO}_{3}-\mathrm{N}_{1} \mathrm{NH}_{4}-\mathrm{N}$ and $\mathrm{PO}_{4}-\mathrm{P}$ in August $1990-1992$ at 4 stations representing different subareas of the eastern Gulf of Finland

Total N:P ratio varied between 10 and 20 and did not show any clear trend along the salinity gradient (Fig. 5c) in spite of the dramatic changes in corresponding total nutrient concentrations (Fig. $5 \mathrm{a}$, b). In salinities $>2$ psu, the 1990 cruise differed clearly from other cruises, showing total N:P ratios over 20 (w: w).

Both inorganic $\mathrm{N}\left(\mathrm{DIN}=\mathrm{NO}_{3}+\mathrm{NH}_{4}\right)$ and inorganic $\mathrm{P}\left(\mathrm{DIP}=\mathrm{PO}_{4}\right)$ displayed very steep concentration decreases immediately outside Neva Bay, where 300 to $600 \mathrm{mg} \mathrm{N} \mathrm{m}^{-3}$ and 15 to $30 \mathrm{mg} \mathrm{P} \mathrm{m}^{-3}$ were measured
(Fig. 5d, e; note the log scales). Typical open Gulf values for DIP $\left(<2 \mathrm{mg} \mathrm{P} \mathrm{m}^{-3}\right)$ were usually reached within the estuarine waters. However, for DIN the corresponding level $\left(<10 \mathrm{mg} \mathrm{N} \mathrm{m}^{-3}\right.$ ) was reached already within the inner estuary in August 1991, but not until the open GuIf in 1992. In general, the relative variation of DIN between the different cruises was much stronger than that of DIP.

The pronounced variations in DIN vs salinity could be seen also in the dependence of the inorganic N:P 
ratio on salinity (Fig 5f). Values generally decreased from Neva Bay (10 to $30 \mathrm{w}: \mathrm{w}$ ) towards the open Gulf (2 to 10 ). Particularly in the salinity range from 2.5 to $3.5 \mathrm{psu}$, i.e. in the outer estuary, the variation under different physical conditions was pronounced (from 0.5 to 40). Usually the theoretical optimum for phytoplankton (N:P = $7 \mathrm{w}: \mathrm{w}$; Redfield et al. 1963) was reached within estuarine waters. However, in 1991 this value was achieved immediately outside the protection barrier in the inner estuary, while in 1992 the level was not reached until in the westernmost open waters of the eastern Gulf

\section{Vertical distribution of inorganic nutrients}

In spite of the high nutrient loading of the Neva Estuary (see 'Study area'), inorganic nutrient concentrations were consistently very low in the productive surface layer of the open Gulf (Fig. 6). However, the depth of this layer differed remarkably between the successive years, in obvious relation to MLD (Figs. $3 \mathrm{~b}$ \& 4).

In 1990, especially nitrate concentrations began to steeply increase with depth already at $10 \mathrm{~m}$ in the open Gulf (Fig. 6). This was aggravated towards the outer estuary, where very high nitrate concentrations (250 $\mathrm{mg} \mathrm{N} \mathrm{m}^{-3}$ ) were encountered already at $20 \mathrm{~m}$. Coupled to the steep nitrate increase with depth in the estuarine area, high ammonium concentrations (up to $50 \mathrm{mg} \mathrm{N} \mathrm{m}^{-3}$ ) were measured at the bottom of the euphotic layer $(10 \mathrm{~m})$. The inner estuary showed high concentrations of all inorganic nutrients both at the surface and near the bottom, with clear minima in between.

In 1991, inorganic nutrients were scarce in the productive surface layer throughout the study area, and this low-nutrient layer extended down to 10 to $20 \mathrm{~m}$ in the open Gulf and in the gradient area at the entrance to the outer estuary (Fig. 6). Maximum nitrate concentrations were detected at $40 \mathrm{~m}$ depth in the open Gulf, i.e. $20 \mathrm{~m}$ deeper than in 1990. A noteworthy feature of inorganic nutrient distributions in 1991 were the uniformly elevated ammonium concentrations (ca $50 \mathrm{mg} \mathrm{N} \mathrm{m}^{-3}$ ) from the lower part of the euphotic layer down to the bottom.

In 1992, inorganic nutrients increased clearly with depth also from $20 \mathrm{~m}$ depth on as in 1991, but concentrations in the surface layer (especially those of nitrate) were clearly elevated from the typical near-zero levels in the outer estuary and at the entrance to the estuary (Fig. 6)

\section{Vertical distribution of inorganic N:P ratio}

Vertical distribution of the inorganic N:P ratio reflected clearly the differences in physical conditions between successive years. In 1990, very clear excess of inorganic $N$ (compared to the Redfield ratio of 7) prevailed in the uppermost $20 \mathrm{~m}$ in the estuarine area (Fig. 7). In contrast, surface layer $\mathrm{N}: \mathrm{P}$ ratios were clearly below 7 in the open Gulf. In all stations, the inorganic N:P ratio approached the Redfield ratio at 30 to $40 \mathrm{~m}$, and in the deep open Gulf near-bottom values fell below 7

In 1991, low surface values of inorganic nutrients (Fig. 6) were coupled with low (mostly $<7$ ) N:P ratios (Fig. 7). From $10 \mathrm{~m}$ to the bottom, ratios were consistently close to 7 , except for the deep open Gulf, where low values were again observed near the bottom (Fig. 7).

In 1992, the high levels of inorganic nutrients (especially of DIN, Fig. 6) were coupled to high inorganic $N: P$ ratios (10 to 30 ) in the whole estuarine area from surface to $20 \mathrm{~m}$, whereas in the middle open Gulf surface layer values decreased to values below 7 as also in 1990-1991 (Fig. 7)

\section{Nutrient depletion experiments}

Experimental nutrient depletion rates illustrate not only the high nutrient uptake potential of the estuarine plankton communities, but also strong variations between the different subareas and between the successive years. During all years, estuarine communities demonstrated both nitrate and ammonium
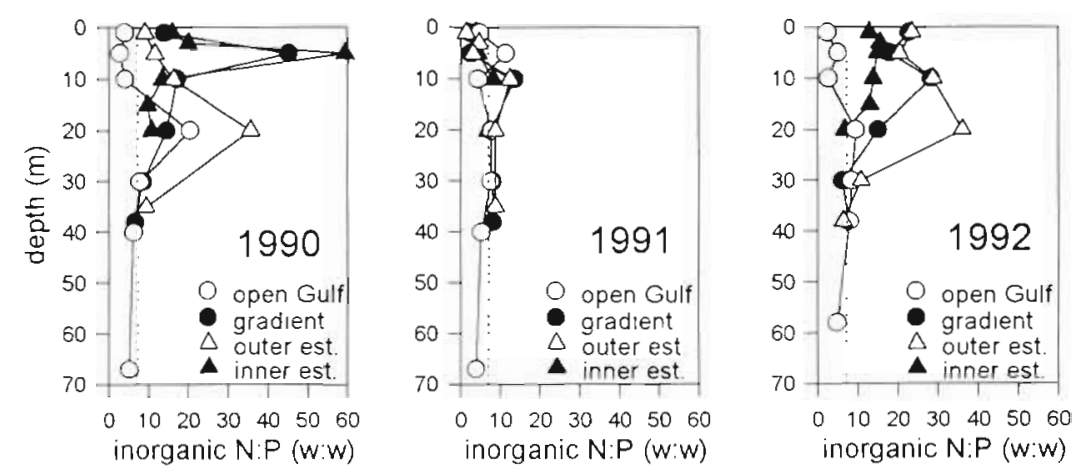

Fig. 7 Vertical distribution of the inorganic N:P ratio in August 1990-1992 at 4 stations representing different subareas of the eastern Gulf of Finland. The dotted lines represent the Redfield ratio ( $7 w: w$ ) 

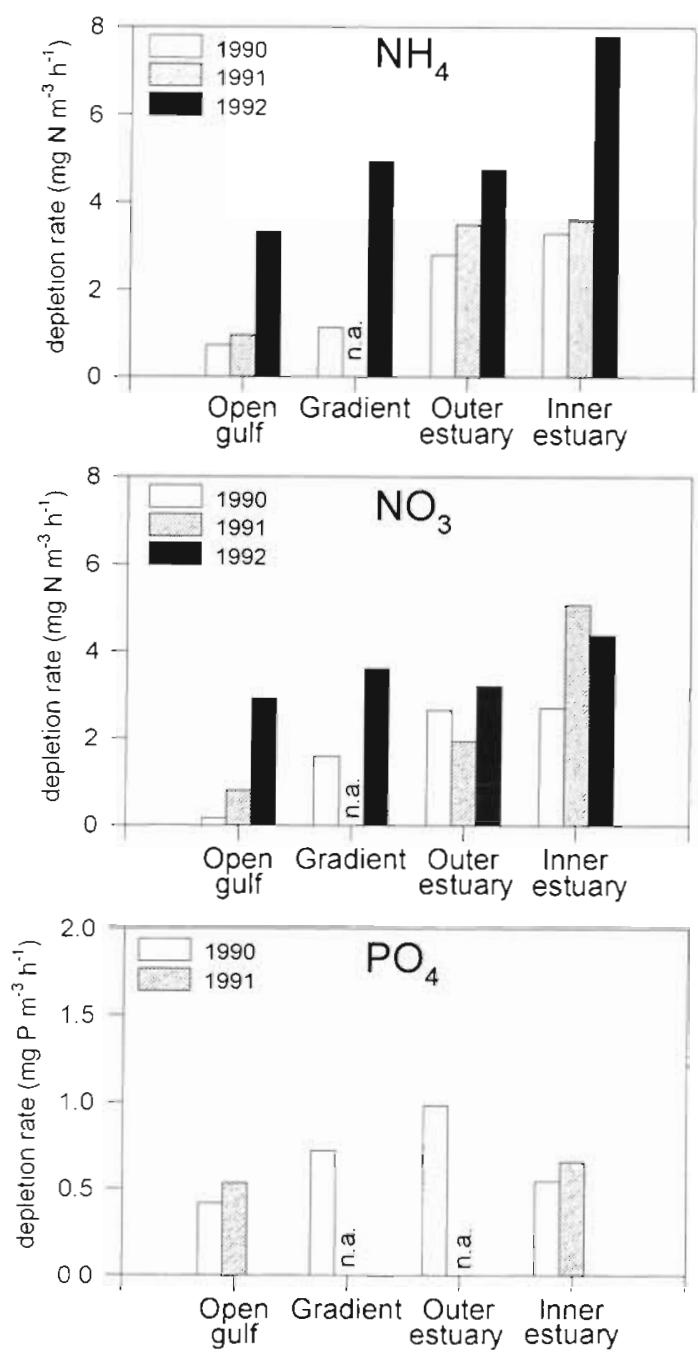

Fig. 8. Experimental depletion rates of $\mathrm{NO}_{3}-\mathrm{N}, \mathrm{NH}_{4}-\mathrm{N}$, and $\mathrm{PO}_{4}-\mathrm{P}$ by natural plankton communities at 4 stations representing different subareas of the eastern Gulf of Finland in August 1990-1992

uptake potential in the range of 2 to $5 \mathrm{mg} \mathrm{N} \mathrm{m}^{-3} \mathrm{~h}^{-1}$ (Fig. 8).

In 1990 and 1991, nitrogen uptake potential clearly decreased towards the open Gulf $\left(<1 \mathrm{mg} \mathrm{N} \mathrm{m}^{-3} \mathrm{~h}^{-1}\right)$. In 1992, however, high values were found in all subareas, with maximum $\mathrm{NH}_{4}$ depletion rates of $8 \mathrm{mg} \mathrm{N} \mathrm{m}^{-3} \mathrm{~h}^{-1}$ (Fig. 8). Phosphate uptake (0.4 to $1.0 \mathrm{mg} \mathrm{P} \mathrm{m}^{-3} \mathrm{~h}^{-1}$ ), measured only in 1990 and 1991, varied less between the different areas, and the open Gulf communities showed high $\mathrm{P}$ uptake potential when compared to corresponding $\mathrm{N}$ values.

When nutrient depletion rates are normalized against chlorophyll a values (Fig. 9), estuarine communities did not deviate consistently from those of the open Gulf. Interannual differences of normalized depletion values were irregular in the estuary. In the open Gulf,

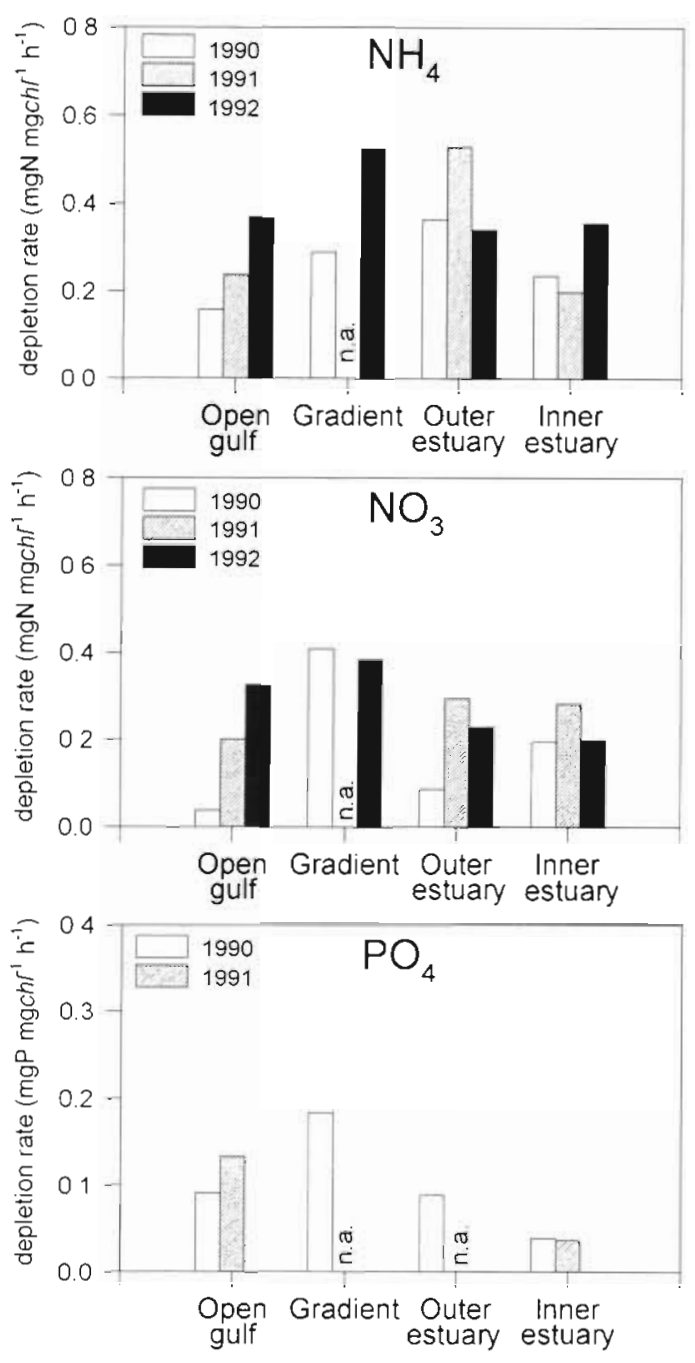

Fig. 9. Experimental depletion rates per unit chlorophyll of $\mathrm{NO}_{3}-\mathrm{N}, \mathrm{NH}_{4}-\mathrm{N}$ and $\mathrm{PO}_{4}-\mathrm{P}$ by natural plankton communities at 4 stations representing different subareas of the eastern Gulf of Finland in August 1990-1992

nitrogen uptake potential per unit chlorophyll was clearly higher in 1992 than during the previous years.

\section{DISCUSSION}

\section{Variations in nutrient dynamics and N:P ratio during estuarine mixing}

The voluminous nutrient flux from Neva Bay into the actual estuary was characterized by a high inorganic $\mathrm{N}$ :P ratio (from 10 to $30 \mathrm{w}$. w, Fig. 5f) when compared to the theoretical optimum for phytoplankton. ( $7 \mathrm{w}: \mathrm{w}$; Redfield et al. 1963). The huge nutrient influx would thus suggest an obvious P limitation of the estuary and adjacent waters of the Gulf of Finland. However, the 
Table 1. Generalization of hydrographic characteristics and nutrient dynamics of subareas of the eastern Gulf of Finland under late summer conditions

\begin{tabular}{|c|c|c|c|c|c|c|}
\hline $\begin{array}{l}\text { Surface } \\
\text { salinity } \\
\text { (psu) }\end{array}$ & Subarea & Thermocline & $\begin{array}{l}\text { Permanent } \\
\text { halocline }\end{array}$ & $\begin{array}{l}\text { Loss of } \mathrm{N} \text { and } \mathrm{P} \\
\text { from euphotic } \\
\text { layer }\end{array}$ & $\begin{array}{l}\text { DIN/DIP of } \\
\text { euphotic } \\
\text { layer (w:w) }\end{array}$ & $\begin{array}{c}\text { Most probable } \\
\text { limiting } \\
\text { nutrients }\end{array}$ \\
\hline$<0.1$ & Neva Bay & Missing & Missing & Small & $10-30$ & $(P)^{d}$ \\
\hline $0.1-2$ & Inner estuary & Strong & Missing & Very effective & $5-30$ & $P,(N)^{b}$ \\
\hline $2-3$ & Outer estuary & Strong & Hoak & Modest & $1-40$ & $P, N$ \\
\hline $3-4$ & Transition zone & Strong & Missing & Small & $2-40$ & $\mathrm{~N}, \mathrm{P}$ \\
\hline$>4$ & Open eastern Gulf & Strong & Weak & Small & $2-10$ & $N$ \\
\hline
\end{tabular}

development of both inorganic and total N:P ratios (Fig. 5c, f) in the estuarine waters revealled processes that significantly affect the limitation pattern.

In order to examine these processes, the study area can be treated as 5 successive surface salinity regimes, each showing different nutrient dynamics (Table 1). These salinity regimes roughly correspond to the different estuarine subareas (Fig 2), although areal variability naturally exists, depending on prevailing physical conditions of the water mass. Especially in August 1991, the salinity pattern of the eastern Gulf was exceptional, and very low salinities (1 to 1.5 psu lower than normal) were detected in the surface layer of the outer Neva Estuary and of the northeastern open Gulf (Fig. 3a).

Both DIN and DIP showed an order-of-magnitude decrease in the salinity regime from 0 to 2 psu (the inner estuary), and the decrease was extremely nonlinear in relation to salinity (Fig. 5d, e). Together with the substantial losses of total $\mathrm{N}$ and $\mathrm{P}$ this means that large amounts of inorganic $\mathrm{N}$ and $\mathrm{P}$ were transformed to other chemical forms during the mixing process and transferred from the surface layer. The losses must be mostly due to the high biological activity of the inner

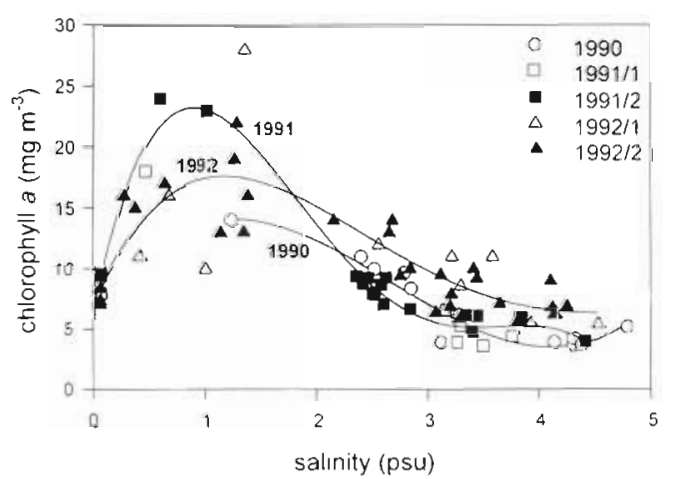

Fig. 10. Surface layer ( 0 to $5 \mathrm{~m}$ ) chlorophyll a concentration vs salinity during crusses in August 1990-1992 estuary. High nutrient depletion potential (Fig. 8), high chlorophyll a values (Fig. 10) and high amounts of plankton, especially blue-green algae (Pitkänen et al. 1993, Kauppila et al. 1995), were all evidence of intense uptake of nutrients outside the flood protection barrier in the inner estuary.

The inorganic N:P ratio displayed a strong and nonlinear decrease against the salinity gradient in the inner estuary (1991, Fig. 5f) or at latest in the outer estuary (1992). The decrease can be explained by several biogeochemical processes (Pitkänen 1991).

(1) Denitrification removes $N$ in all studied estuarine systems (e.g. Seitzinger 1988). The steady vertical distribution of nitrate below the pycnocline, with the ammonium maximum immediately below the mixed surface layer of the eastern Gulf (Fig. 6), indicates that this process may also take place in the organic flocs present in the free water. On the other hand, the role of the opposite process, fixation of $\mathrm{N}_{2}$, is probably negligible due to small amounts of $\mathrm{N}_{2}$-fixing blue-green algae in the estuary (Howarth 1988, Pitkänen et al. 1993, Kauppila et al. 1995).

(2) Increasing pH and decreasing DIP concentration along the salinity gradient favour release of adsorbed $P$ from riverine particulate matter (e.g Pomeroy et al. 1965, Froelich 1988), while a large fraction (ca 50\%, Fig. $5 a, d)$ of riverine $N$ is included by the stable dissolved organic fraction (DON) which liberates inorganic N only slowly (Burton 1988).

(3) The capacity of the saline water sediments to permanently retain $\mathrm{P}$ is generally poorer compared to that of freshwater sediments because of the formation of insoluble Fe(II)S in anoxic saline water sediments. This process reduces the potentially available adsorption sites for P (Caraco et al. 1990).

(4) The near-bottom flow from the open Gulf, which mixes with the surface layers especially in the inner estuary has an inorganic N:P ratio considerably lower (5 to $10 \mathrm{w}: \mathrm{w}$ ) than the flux from Neva Bay (10 to $30 \mathrm{w}: \mathrm{w}$ ). Denitrification and liberation of DIP from sus- 


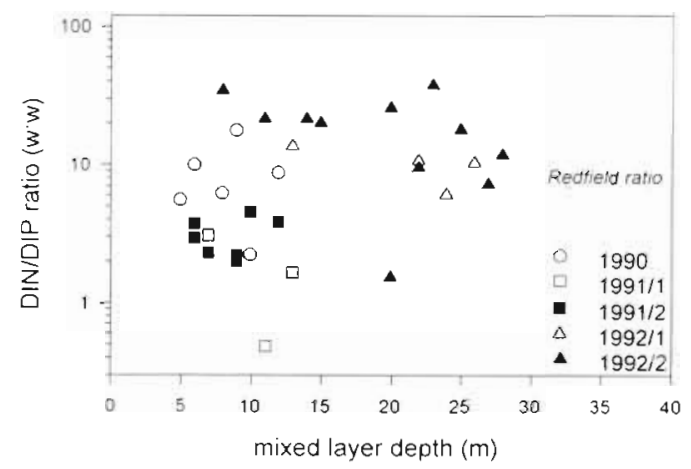

Fig. 11. Inorganic N:P ratio vs mixed layer depth (MLD) in the outer Neva Estuary and in the transition zone between the estuary and the open Gulf in August 1990-1992

pended particulate matter and from the bottom sediment tend to keep this ratio low

(5) Several blue-green algal species, e.g. Planktothrix agardhii, one of the dominant species in the estuary (Kauppila et al. 1995), accumulate extra P in their cells when they are in aphotic, nutrient-rich waters (Raynolds \& Walsby 1975) and transfer P to the euphotic layer via vertical mixing of the mixed surface layer.

(6) The lower thermocline maxima of the inorganic $N: P$ ratio of the estuary (up to 30 to $40 \mathrm{w}: \mathrm{W}$ in 1990 , Fig. 7) and the general decrease of this ratio in the euphotic layer during the estuarine mixing suggest that the net losses of $\mathrm{N}$, via sedimentation of autochthonous POM, are relatively greater than those of $\mathrm{P}$. The same phenomenon has been experimentally observed in studies in the coastal western Gulf (Tamminen 1989, Heiskanen \& Leppänen 1995).

Thus the circulation of bioavailable $P$ in the planktonic food web of the euphotic layer is probably more effective than that of $N$, leading to the observed decrease in the inorganic N:P ratio. On the other hand, the inorganic N:P maxima in the thermocline region (Fig. 7) means that as a result of intensified vertical mixing, e.g. as a result of heavy winds, erosion of the pycnocline transfers water rich in $\mathrm{N}$ to the euphotic layer (Fig. 11). Thus nutrional conditions can rapidly change from $\mathrm{N}$ deficiency to nutrient balance or to $\mathrm{P}$ deficiency in the estuarine waters.

\section{Losses of $\mathrm{N}$ and $\mathrm{P}$ from the euphotic layer}

The behaviour of the total N:P ratio (Fig. 5c) showed that biological processes are able to explain only a part of the losses of total $P$ from the surface layer. The increasing or steady total N:P ratio in the inner estuary despite decreasing inorganic N:P ratios (Fig. 5f) and strongly decreasing total $N$ concentrations (Fig. 5a), indicated effective removal of total $P$ (representing both particulate $P$ and dissolved organic $P$ f from the surface layer. Because most of the removal took place in the inner estuary, i.e. in the region where effective mixing of river water and saline water takes place. flocculation and precipitation of colloidal and particulate riverine matter into settlable aggregates (e.g. GESAMP 1987) probably was the primary reason for these losses.

The dependencies of both total $\mathrm{N}$ and $\mathrm{P}$ on salinity appeared very consistent (Fig. 5a, b). Thus it is possible to roughly estimate magnitudes of the net losses of total nutrients from the euphotic layer of the inner estuary. When the linear relations between nutrients and salinity (the dilution dominated area from 2 to $4-5$ psu) are extrapolated to the salinity of 0 psu, amounts of $37 \mathrm{mg} \mathrm{P} \mathrm{m}^{-3}$ and $500 \mathrm{mg} \mathrm{N} \mathrm{m}^{-3}$ are found to be lost from the surface layer by vertical transport. The real losses of $\mathrm{N}$ and $\mathrm{P}$ are even greater, because the deeper flow, which gradually mixes with the upper layers especially in the inner estuary, contains clearly higher concentrations of both $\mathrm{N}$ and $\mathrm{P}$ than the open Gulf surface layer (Pitkänen 1991, Pitkänen et al. 1993).

Only a small part of the voluminous nutrient losses from the euphotic surface layer of the inner estuary settled permanently on the bottoms of the shallow and physically very variable inner estuary. Due to effective mineralisation of the high autochthonous production already in the thermocline region $\left(\mathrm{NH}_{4}-\mathrm{N}\right.$ up to $100-$ $150 \mathrm{mg} \mathrm{N} \mathrm{m}^{-3}$, Fig. 6), outstanding amounts of both DIN (150 to $300 \mathrm{mg} \mathrm{N} \mathrm{m}^{-3}$ ) and DIP (20 to $50 \mathrm{mg} \mathrm{P} \mathrm{m}^{-3}$ ) accumulated in sub-euphotic waters. Because the average direction of surface flow in the inner estuary is towards west (Pitkänen et al. 1993), a part of the nutrient losses from the euphotic layer were transported towards the outer estuary in sub-euphotic layers, both as mineralized and particulate fractions. The main sedimentary basin of the estuary covers an area of ca $1200 \mathrm{~km}^{2}$ (Pitkänen 1994). This area provides favourable conditions for effective sedimentation and denitrification.

If the late summer conditions are assumed to roughly represent average annual conditions between springtime maximum and wintertime minimum, the estimated concentration differences would suggest annual net losses of $39000 \mathrm{t} \mathrm{N} \mathrm{Yr}^{-1}$ and $2900 \mathrm{t} \mathrm{P} \mathrm{yr}^{-1}$ from the surface layer of Neva Estuary when mean annual river flow of $2460 \mathrm{~m}^{-3} \mathrm{~s}^{-1}$ (Bergström \& Carlsson 1994) is applied. If we assume that these amounts are permanently retained or removed in the estuarine waters (surface area $3200 \mathrm{~km}^{2}$ ), average amounts of $12 \mathrm{~g} \mathrm{~N}$ $\mathrm{m}^{-2} \mathrm{yr}^{-1}$ and $0.9 \mathrm{gP} \mathrm{m}^{-2} \mathrm{yr}^{-1}$ are obtained. The estimated figures correspond well with estimates of total net losses (sedimentation and denitrification) for the 
entire eastern Gulf $\left(7.6 \mathrm{~g} \mathrm{~N} \mathrm{~m}^{-2} \mathrm{yr}^{-1}\right.$ and $0.6 \mathrm{~g} \mathrm{P} \mathrm{m}^{-2}$ $\mathrm{yr}^{-1}$; Pitkänen 1991), when the higher planktonic production and more sheltered topography of the Neva Estuary are taken in account.

\section{Role of $\mathrm{N}$ and $\mathrm{P}$ as production limiting factors}

Despite the high and continuous inputs of DIN and DIP into the Neva Estuary these nutrients were in most cases exhausted from the euphotic layer already within the estuarine area, sometimes even in the inner estuary (Fig. 5c, d). The nutrient depletion experiments in the present study indicated very effective nutrient uptake of the estuarine plankton community (Figs. 8 \& 9). Although physical conditions are variable, especially certain blue-green algae are able to maintain consistently blooming populations in the area (Pitkänen et al. 1993, Kauppila et al. 1995), causing effective uptake of nutrients and sedimentation from the euphotic layer.

The estuarine 2 -layer flow system with average outflow in the surface layer and inflow in deeper waters, as well as good oxygen conditions ( $>50 \%$ saturation; Pitkänen et al. 1993) in the near-bottom waters favour permanent retention and removal of nutrients (Pitkänen 1991). A lot of variation existed, however, in the dynamics of $\mathrm{N}$ and $\mathrm{P}$, depending on the actual physical conditions of the water mass. This led to very strongly varying nutrient conditions and $\mathrm{N}: \mathrm{P}$ ratios of the euphotic layer, depending largely on actual weather conditions (Table 1).

In the innermost estuary, inside the flood protection barrier, nutrient concentrations were high (Fig. 5), but due to high turbidity and short residence time (Pitkänen et al. 1993), primary production is physically limited, which was reflected in the low chlorophyll levels of the area (Fig. 10). Only in certain near-shore waters outside the main route of the Neva flow through the barrier basin might DIP be exhausted.

Immediately outside the barrier the inorganic N:P ratio started a rapid decrease. If MLD (Fig. 3b) is $>10 \mathrm{~m}$, as it was in 1992, the euphotic layer easily obtains nutrient replenishment from the aphotic subsurface waters. This allowed considerable DIN concentrations (10 to $70 \mathrm{mg} \mathrm{N} \mathrm{m}^{-3}$ ) and high inorganic $\mathrm{N}: P$ ratios (10 to $40 \mathrm{w}: \mathrm{w}$ ) to be maintained throughout the inner estuary and also in most parts of the outer estuary (Fig. 11) and led to a probable $P$ deficiency in the primary production. In the case of a thin or moderate MLD $(<10 \mathrm{~m})$, the relative net loss of DIN was much more rapid than that of DIP and replenishment of DIN from deeper waters was restricted. As a result low DIN concentrations $\left(<5 \mathrm{mg} \mathrm{N} \mathrm{m}^{-3}\right.$ ) and inorganic N:P ratios $(<3 \mathrm{w}: \mathrm{w})$ prevailed. Thus $\mathrm{N}$ deficiency can as well occur even within estuarine waters. The result is in good accordance with the sedimentation studies made in the western Gulf of Finland by Heiskanen \& Leppänen (1995).

The results obtained in August 1991 reveal that under exceptional physical conditions of a thin and low-saline mixed surface layer (Fig 3b), eutrophying effects of the large nutrient load into Neva Bay can reach Finnish territorial waters $80 \mathrm{n}$ miles $(150 \mathrm{~km})$ from the mouth of the River Neva. According to the bimonthly monitoring performed in eastern Finnish territorial waters since 1983 , this is the only recorded occasion when a distinct low saline layer has been observed this far from the actual estuary during summer.

In the transition zone between the estuary and the open Gulf, nutrional conditions were stabilized towards the normal open Gulf conditions (theoretical N deficiency, Table 1, Fig. 5f). This means that if the inorganic N:P ratio of the surface layer was high in the outer estuary, it drastically decreased in this zone. Under the condition of a thick mixed surface layer, there might be substantial amounts of available DIN (up to $50 \mathrm{mg} \mathrm{N} \mathrm{m}^{-3}$ ) in the northern part of the study area, far from the actual estuary, due to the average westward flow from the Neva Estuary along the northern coast. Under such conditions primary production was clearly P limited also in these open Gulf waters. In the middle part of the open eastern Gulf, $\mathrm{N}$ deficiency was more likely also in this case.

In salinities over 4 psu (the open Gulf), the inorganic $\mathrm{N}$ :P ratio in most cases stabilized to a level below 7 (Table 1, Fig. 5f). Thus, regarding the most probable limiting nutrient under summer conditions, the open eastern Gulf does not significantly differ from the western Gulf, where, according to extensive mesocosm experiments (Tamminen 1990, Kivi et al. 1993), N proves to be the key limiting nutrient. The same situation is valid in the open Baltic proper as well (Granéli et al. 1990).

\section{CONCLUSIONS}

In addition to its efficient capacity in retaining and removing nutrients, the Neva Estuary strongly transforms the nutrional conditions for phytoplankton from an obvious $P$ deficiency in the inner estuary to a probable $N$ deficiency in the open eastern Gulf In practice this means that if water protection measures in the future are only aimed at phosphorus removal from waste waters, planktonic production would decrease mainly in the estuarine waters of the easternmost Gulf. Probably no particular advances would likely occur in the open Gulf under summer conditions, because of the internal processes of the estuary which strongly 
decrease the high inorganic N:P ratio of the nutrient loading to the euphotic layer. To achieve a more extensive decrease in the trophic status of the Gulf, as much as possible of the voluminous $\mathrm{N}$ inputs should evidently be removed, in addition to Premoval.

Acknowledgements. The study is based on a joint FinnishRussian research project carned out in the eastern Gulf of Finland (Water and Environment Research Institute, Finland, and State Hydrological Institute, Russia) on board RV 'Mulkku' Corresponding authorities and the whole crew of Muikku, including laboratory technicians Elina Salminen (PELAG) and Leena Kurkela (Kymi Water and Environment District), are warmly thanked for good cooperation. On behalf of T.T this study is a contribution to the project PELAG, Tvärminne Zoological Station, Finland.

\section{LITERATURE CITED}

Bergström S, Carisson B (1994) River runoff to the Baltic Sea: 1950-1990. Ambio 23:280-285

Burton JP (ed) (1988) Rivex inputs to ocean systems: status and recommendations for research. UNESCO Tech Pap mar Res 46

Caraco $N$ (1988) What is the mechanism behind the seasonal switch between $\mathrm{N}$ and $\mathrm{P}$ limitation in estuaries? Can J Fish Aquat Sci 45:381-382

Caraco N, Cole J, Likens GE (1990) A comparison of phosphorus immobilization of freshwater and coastal marine systems. Biogeochemistry 9:277-290

Froelich PN (1988) Kinetic control of dissolved phosphate in natural rivers and estuaries. Limnol Oceanogr 33: $649-668$

GESAMP-IMO/FAO/UNESCO/WMO/IAEA/UN/UNEP Joint Group of Experts on the Scientific Aspects of Marine Pollution (1987) Land/sea boundary flux of contaminants: contribution from rivers. UNESCO Rep Stud 32

Granéli E, Wallström K, Larsson U, Granéli W, Elmgren R (1990) Nutrient limitation of primary production in the Baltic Sea area. Ambio 19:142-151

Grasshoff K (1976) Methods of seawater analysis. Verlag Chemie, Weinheim

Grönlund L, Leppänen JM (1990) Long-term changes in the nutrient reserves and pelagic production in the western Gulf of Finland. Finn mar Res 257:15-27

Heiskanen AS, Leppänen JM (1995) Estimation of export production in the coastal Baltic Sea: effect of resuspension and microbial decomposition on sedimentation measurements. Hydrobiologia (in press)

Howarth RW, Manno R, Cole JJ (1988) Nitrogen tixation in freshwater, estuarine and marine ecosystems. 2. Biogeochemical controls. Limnol Oceanogr 33:688-701
Kahma K, Voipio A (1990) Elimination of seasonal variation from longterm changes of some nutrients in the Baltic Sea. Finn mar Res 257:3-14

Kauppila P, Hällfors G, Kangas P, Kokkonen P, Basova S (1995) Late summer phytoplankton species composition in the eastern Gulf of Finland. Ophelia 42:179-191

Kivi $K$, Kaitala S, Kuosa H, Kuparinen J, Leskinen E, Lignell R, Marcussen B, Tamminen T (1993) Nutrient limitation and grazing control of the Baltic plankton community during annual succession. Limnol Oceanogr 38:893-905

Kononen K, Nômmann S (1992) Spatio-temporal dynamics of the cyanobacterial blooms in the Gulf of Finland, Baltic Sea. In: Carpenter E J, Capone D, Rueter J (eds) Marine pelagic Cyanobacteria: Trichodesmium and other diazotrophs. Kluwer, Dordrecht, p 95-113

Kuparinen J, Heinänen A (1993) Inorganic nutrient and carbon controlled bacterioplankton growth in the Baltic Sea. Estuar coast Shelf Sci 37:271-286

Pitkänen $\mathrm{H}$ (1991) Nutrient dynamics and trophic conditions in the Eastern Gulf of Finland: the regulatory role of the Neva Estuary. Aqua Fennica 21: 105-115

Pitkänen H (1994) Eutrophication of the Finnish coastal waters: origin, fate and effects of riverine nutrient fluxes. National Board of Waters and the Environment, Findland. Publications of the Water and Environment Research Institute 18:1-44

Pitkänen $\mathrm{H}$, Tamminen $T$, Kangas P, Huttula T, Kivi K, Kuosa H, Sarkkula J, Eloheimo K, Kauppila P, Skakalsky B (1993) Late summer trophic conditions in the north-east Gulf of Finland and the River Neva Estuary, Baltic Sea. Estuar coast Shelf Sci 37:453-474

Pomeroy LR, Smith EE, Grant CM (1965) The exchange of phosphate between estuarine water and sediments. Limnol Oceanogr 10:167-172

Redfield AC, Ketchum BH, Richards FH (1963) The influence of organisms on the composition of seawater. In: Hill MN (ed) The sea, Vol 2. Wiley, New York, p 26-77

Reynolds CS, Walsby AE (1975) Water blooms. Biol Rev 50 $437-481$

Seitzinger SP (1988) Denitrification in freshwater and coastal marine ecosystems: Ecological and geochemical significance. Limnol Oceanogr 33:702-724

Stigebrandt A, Wulff $F$ (1989) A model for the dynamics of nutrients and oxygen in the Baltic proper. $J$ mar Res 45:729-759

Tamminen $T$ (1989) Dissolved organic phosphorus regeneration by bacterioplankton: 5 '-nucleotidase activity and subsequent phosphate uptake in a mesocosm enrichment experiment. Mar Ecol Prog Ser 58:89-100

Tamminen T (1.990) Eutrophication and the Baltic Sea: studies on phytoplankton, bacterioplankton, and pelagic nutrient cycles. PhD thesis, Univ of Helsinki, Dept of Environmental Conservation

Yurkovskis A, Wultt F, Rahm L, Andruzaitis A, RodriguezMedina M (1993) A nutrient budget of the Gulf of Riga, Baltic Sea. Estuar coast Shelf Sc1 37:113-127

Manuscript first received: November 11, 1994

Revised version accepted: April 12, 1995 